\title{
Improvement of the viability of probiotics (Lactobacillus acidophilus) by multilayer encapsulation
}

\author{
Maria Fernanda da Silveira Cáceres de Menezes $^{1}$ Thaiane Marques da Silva ${ }^{1}$ iD \\ Mariana de Araújo Etchepare ${ }^{1}$ Bruna de Souza Fonseca $^{1}$ Vandré Pinto Sonza $^{1}$ \\ Cristiane Franco Codevilla ${ }^{1}$ (D) Juliano Smanioto Barin ${ }^{1}$ Cristiane de Bona da Silva ${ }^{2}$ \\ Cristiano Ragagnin de Menezes $^{1^{*}}$ (iD)
}

'Departamento de Ciência e Tecnologia de Alimentos, Universidade Federal de Santa Maria (UFSM), 97105-900, Santa Maria, RS, Brasil. E-mail: cristiano.ufsm@gmail.com. ${ }^{*}$ Corresponding author.

${ }^{2}$ Departamento de Farmácia, Universidade Federal de Santa Maria (UFSM), Santa Maria, RS, Brasil.

ABSTRACT: This study produced pectin microcapsules containing Lactobacillus acidophilus by external ionic gelation, followed by the adsorption of whey protein and pectin to form multilayers. The viability of free and microencapsulated lactobacilli was evaluated after in vitro exposure to gastrointestinal conditions. They were also assessed by heat treatment, and stability was examined at $-18{ }^{\circ} \mathrm{C}, 5^{\circ} \mathrm{C}$ and 25 ${ }^{\circ} \mathrm{C}$ for 120 days. Exposure to different $\mathrm{pHs}$, simulating passage through the gastrointestinal tract, showed that treatment of the microcapsules with only pectin ( $L A / P O)$ and with one and two layers of whey protein (treatments LA/PI and LA/P3, respectively), were able to protect Lactobacillus acidophilus, with microcapsules increasing the release of probiotics from the stomach into the intestines. Free cells showed a decrease in their counts over the course of the simulated gastrointestinal system. Regarding heat treatments, microcapsules with a layer of whey protein (LA/P1) maintained the viability of their encapsulated Lactobacillus acidophilus $\left(9.57 \log C F U / \mathrm{g}^{-1}\right)$. The best storage viability was at $-18^{\circ} \mathrm{C}$, with a count of $7.86 \log C F U / g^{-1}$ at 120 days for microcapsule $L A / P 1$, with those consisting of two layers of whey protein (LA/P3) having a $6.55 \log C F U / g^{-1}$ at 105 days. This study indicated that external ionic gelation was effective and could be used for the production of pectin microcapsules, with multilayer whey protein promoting greater protection and viability of Lactobacillus acidophilus. Key words: pectin, whey protein concentrate, external ionic gelation.

Melhoramento da viabilidade de probióticos (Lactobacillus acidophilus) por encapsulação em multicamadas

RESUMO: O objetivo deste trabalho foi produzir microcápsulas de pectina, contendo Lactobacillus acidophilus por gelificação iônica externa, seguida da adsorção de proteina de soro de leite e multicamadas formadoras de pectina. Além disso, a viabilidade de lactobacilos livres e microencapsulados, após exposição in vitro a condições gastrintestinais, foi avaliada após simulação de tratamentos térmicos e, finalmente, estabilidade $a-18{ }^{\circ} \mathrm{C}, 5{ }^{\circ} \mathrm{C}$ e $25{ }^{\circ} \mathrm{C}$ durante 120 dias de armazenamento. A exposição a diferentes pHs, simulando a passagem pelo trato gastrointestinal, mostrou que os tratamentos das microcápsulas com apenas pectina (LA/P0) e com uma e duas camadas proteína do soro (tratamentos LA/P1 e LA/P3, respectivamente), foram capazes de proteger o Lactobacillus acidophilus , enquanto as microcápsulas aumentaram a liberação de probióticos do estômago para o intestino. As células livres diminuíram suas contagens no curso do sistema. Em relação aos tratamentos térmicos aplicados, pode-se afirmar que a microcápsula com uma camada de proteina do soro (LA/P1) resistiu e manteve a viabilidade de Lactobacillus acidophilus $\left(9,57 \log C F U / g^{-1}\right)$. A melhor viabilidade foi obtida no armazenamento a $-18^{\circ} \mathrm{C}$, com uma contagem de 7,86 log CFU / g $\mathrm{g}^{-1}$ para essa mesma microcápsula (LA/P1) no final do armazenamento (120 dias) e 6,55 log CFU / $\mathrm{g}^{-1}$ para as microcápsulas com duas camadas de proteína do soro (LA/P3) por 105 dias. Este estudo indica que a gelificação iônica externa é eficaz e pode ser usada para a produção de microcápsulas de pectina com multicamadas de proteína de soro para promover maior proteção e viabilidade ao Lactobacillus acidophilus.

Palavras-chave: pectina, concentrado proteico do soro de leite, gelificação iônica externa.

\section{INTRODUCTION}

Over the years, the term probiotic has undergone some changes in its concept, and today, it is defined as living microorganisms that confer benefit to the health of the host when administered in adequate amounts (WORLD GASTROENTEROLOGY ORGANISATION, 2011). Among the most important probiotics are lactic acid bacteria, such as Lactobacillus acidophilus, due to their beneficial effect on the gastrointestinal tract (ANAL \& SINGH, 2007). 
The viability of probiotics is very important, since they must be alive at the site of action in order to provide health benefits (CHAMPAGNE et al., 2011). However, studies reported that the survival of free probiotic cells in food is low (DE VOS et al., 2010), and they require a physical barrier, resistant to the adverse conditions in the gastrointestinal environment (KAILASAPATHY, 2009).

External ionic gelation forms porous gel particles from a polymer solution containing the probiotic, in the presence of a constantly stirred ionic solution (ECTHEPARE et al., 2016). Electrostatic interactions occur between biopolymers loaded with opposite charges (KRASAEKOOPT et al., 2004). The interaction of biopolymers depends on factors such as polysaccharide-protein relations, $\mathrm{pH}$, ionic strength and polyelectrolyte concentration (SALMINEN \& WEISS, 2014). Many natural polymers have been studied, such as pectin, a raw material that can be obtained commercially or extracted from citrus industry waste. Pectin can form complexes with other polymers, due to its load balance, which is positive at high $\mathrm{pHs}$ and negative at low pHs. As a result, pectin has been associated with other polymers, and evaluated as a coating material by the pharmaceutical and food industries. Because of its functional characteristics, pectin is also considered to be a prebiotic.

Whey protein concentrate is a residual liquid obtained during the coagulation of milk for the production of cheese or casein. It is an important by-product because of its nutritional value, containing high levels of essential amino acids, calcium and bioactive peptides (SOORO INGREDIENTES, 2014). Whey proteins have been used in the microencapsulation of probiotics, since they have functional and technological advantages, mainly from their ability to form gels (PICOT \& LACROIX, 2004; REID, 2008; DOHERTY et al., 2011; GBASSI et al., 2011).

Reports have proposed multilayer coating with proteins as an alternative process, to eliminate porosity, protect microencapsulated compounds and reduce the size of the microparticle obtained by external ionic gelation; however, further studies involving protein multilayer particles and probiotic cultures are required (SOUZA et al., 2012; LIU et al., 2017).

This study produced and characterized pectin microcapsules with multilayers in order to immobilize Lactobacillus acidophilus. Survival of the bacteria in the microcapsules was assessed by passage through a simulated gastrointestinal tract, heat treatments, and storage for 120 days under different temperature conditions.

\section{MATERIALS AND METHODS}

\section{Reagents}

Lactobacillus acidophilus LA02 AF (Probiotical S.p.A., Novara, Italy), low methoxylation citrus pectin (CP Kelco, Limeira, Brazil), de Man, Rogosa and Sharpe (MRS)broth (Himedia Curitiba, Paraná, Brazil), MRS agar (Himedia Curitiba, Paraná, Brazil),calcium chloride (Vetec, Rio de Janeiro, Brazil), hydrochloric acid (Vetec, Rio de Janeiro, Brazil), sodium bicarbonate (Vetec, Rio de Janeiro, Brazil), whey protein concentrate (IMCD Brazil, São Paulo, Brazil), pepsin (Sigma-Aldrich Co, St. Louis, MO, USA), pancreatin (Sigma-Aldrich Co, St. Louis, MO, USA), and bovine bile salts (Sigma-Aldrich Co, St. Louis, MO, USA).

\section{Inoculum preparation}

One g Lactobacillus acidophilus was activated in $100 \mathrm{ml}$ MRS broth for $15 \mathrm{~h}$ at $37{ }^{\circ} \mathrm{C}$. Subsequently, the probiotic was centrifuged in a Hitachi CR22GIII (Tokyo, Japan) at $4670 \times \mathrm{g}$ for $15 \mathrm{~min}$., and then washed with $1 \mathrm{~mL} 0.85 \% \mathrm{NaCl}$. Cells were suspended in saline to approximately $10 \log \mathrm{CFU} / \mathrm{g}^{-1}$.

\section{Production of pectin microcapsules by ionic gelation}

The microcapsules were produced as proposed by ECTHEPARE et al. (2016), with modifications, in which a solution of $2 \%$ low methoxylation pectin $\mathrm{pH} 4.0$ was sprayed by a double fluid atomizer measuring $1 \mathrm{~mm}$ in diameter, at a distance $12 \mathrm{~cm}$ from the tip of the atomizer to the $0.1 \mathrm{M}$ calcium chloride solution. Velocity of the compressed air was $0.555 \mathrm{~mL} / \mathrm{h}$ and the pressure was $0.688 \mathrm{Kgf} / \mathrm{cm}^{2}$. Microcapsules formed were left stirring for 30 minutes in the solution until complete gelation had occurred, and were then filtered through a $53 \mu \mathrm{m}$ diameter steel mesh screen and washed with sterile distilled water at $\mathrm{pH} 4.0$.

\section{Production of multilayer microcapsules}

The methodology proposed by ANNAN et al. (2008) was followed, with adaptations. The $2 \%$ pectin microcapsules were transferred to solutions with different concentrations of whey protein $(2 \%$ and $0.5 \%)$ and pectin ( $2 \%$ and $0.3 \%$ ), according to the proposed treatment and the number of layers, as described in table 1. For each layer adsorption, the solution was stirred at $500 \mathrm{rpm}$ for $30 \mathrm{~min}$. at room temperature.

\section{Encapsulation efficiency}

The encapsulation efficiency was determined according to Equation (1) (DOHERTY et al., 2011): 
Table 1 - Composition of microcapsules with and without multilayers produced by external ionic gelation, encapsulation efficiency of Lactobacillus acidophilus viable cells and mean diameter.

\begin{tabular}{|c|c|c|c|}
\hline Type of Microparticle & Treatment & $\mathrm{EE}(\%)$ & Diameter d (D 4.5) ( $\mu \mathrm{m})$ \\
\hline $\mathrm{LA} / \mathrm{P} 0$ & Pectin $2 \%$ & $87.91+00.6^{\mathrm{a}}$ & $477.6^{\mathrm{a}}$ \\
\hline $\mathrm{LA} / \mathrm{P} 1$ & Pectin $2 \%+$ whey protein concentrate $2 \%$ & $72.50+0.41^{\mathrm{b}}$ & $236.0^{\mathrm{b}}$ \\
\hline $\mathrm{LA} / \mathrm{P} 2$ & Pectin $2 \%+$ whey protein concentrate $2 \%+$ pectin $0.3 \%$ & $62.61+0,22^{\mathrm{c}}$ & $223.0^{\mathrm{b}}$ \\
\hline $\mathrm{LA} / \mathrm{P} 3$ & $\begin{array}{c}\text { Pectin } 2 \%+\text { whey protein concentrate } 2 \%+\text { pectin } 0.3 \%+\text { whey } \\
\text { protein concentrate } 0.5 \%\end{array}$ & $77.34+0.09^{b}$ & $208.0^{\mathrm{c}}$ \\
\hline
\end{tabular}

Means and standard deviation with different letters within the same column were significantly different $(\mathrm{P}<0.05)$. LA $=$ Lactobacillus acidophilus encapsulated in type of microcapsule.

$\mathrm{EE}=\mathrm{N} / \mathrm{N} 0 \times 100$

where $\mathrm{N}=\log \mathrm{CFU} \cdot \mathrm{g}^{-1}$ of the capsule, and $\mathrm{N} 0=\log$ CFU. $\mathrm{g}^{-1}$ of the culture added to the capsule material.

Morphological characterization of microcapsules by optical and scanning electron microscopy

The morphology of the particles was assessed with an Axio Scope Aloptical microscope (Carl Zeiss, Oberkochen, Germany), and microstructure of lyophilized microcapsules was examined with a JSM scanning electron microscope (SEM) (Jeol, Tokyo, Japan).

Mean diameter and size distribution of microcapsules Measurements were taken using a Mastersizer 2000 laser diffraction particle size analyzer (Malvern Panalytical GmbH, Herrenberg, Germany).

\section{Viable cell count}

Samples were prepared as described by SHEU \& MARSHALL (1993) One g microcapsules was added to $9 \mathrm{ml}$ sterile phosphate buffer solution ( $\mathrm{pH} 7.5$ ), and stirred at $500 \mathrm{rpm}$ for 5 minutes at room temperature. Subsequently, serial dilutions were made, with depth plating and addition of MRS agar overlay, in triplicate. Plates were incubation at $37^{\circ} \mathrm{C}$ for $72 \mathrm{~h}$ in anaerobic jars, using an Oxoid anaerobic generator (Thermo Fisher Scientific, Waltham, MA, USA). Storage time survival analysis was performed fortnightly for 120 days, with samples stored in sterile collection bottles at $-18^{\circ} \mathrm{C}, 5^{\circ} \mathrm{C}$ and $25^{\circ} \mathrm{C}$, according to OLIVEIRA et al. (2007).

Evaluation of survival of L. acidophilus submitted to simulated gastrointestinal conditions

The method of MADUREIRA et al. (2011) was used, with modifications. The test consisted of submitting microcapsules to changes in $\mathrm{pH}$ and enzymes that simulated those reported in the esophagus/stomach, duodenum and ileum. For the esophagus/stomach simulation, microcapsules were exposed to pepsin for 90 minutes, with the $\mathrm{pH}$ being gradually reduced to 2.0 with hydrochloric acid. For the duodenum simulation, pancreatin and bile salts were used, and the $\mathrm{pH}$ adjusted to 5.0 for 20 minutes. For the ileum simulation, the $\mathrm{pH}$ was adjusted to 6.5 with sodium bicarbonate, to which the microcapsules were exposed for 90 minutes. At the end of each simulated step, a viable cell count was performed, as described above.

Survival of Lactobacillus acidophilus under heat treatment

The methodology described by ZHANG et al.(2015) was used,with modifications. Free and microencapsulated Lactobacillus acidophilus were submitted to heat treatments of $72{ }^{\circ} \mathrm{C}$ for $15 \mathrm{~s}$ and $63^{\circ} \mathrm{C}$ for $30 \mathrm{~min}$., simulating the processes of fast and slow pasteurization, respectively. One g microcapsule or free probiotic was transferred to test tubes containing $9 \mathrm{~mL}$ peptone water. After the heat treatments in an ultra-thermostat bath, test tubes were cooled in an ice bath for 5-10 min., and viable cell counts were performed as described above.

Viability of Lactobacillus acidophilus on storage at different temperatures

Feasibility of storing free and microencapsulated probiotics was assessed by viable cell counts after $0,15,30,45,60,75,90,105$ and 120 days at $-18{ }^{\circ} \mathrm{C}, 5^{\circ} \mathrm{C}$ and $25^{\circ} \mathrm{C}$.

\section{Statistical analysis}

Three replicates of the treatments were performed and the measurements were taken in triplicate. Subsequently, data were submitted to 
analysis of variance (ANOVA), and differences between the means were verified by Tukey's test $(\mathrm{p}<0.05)$, using Statistic ${ }^{\circledR}$ 7.0. software (Stat soft, Tulsa, OK, USA).

\section{RESULTS AND DISCUSSION}

\section{Encapsulation efficiency and mean diameter of the microcapsules}

The LA/P0 microcapsules showed the highest encapsulation efficiency of $87.91 \%$ (Table 1); and therefore, the largest average particle size when compared to the other treatments. According to CHEN et al. (2017), the larger the capsule size the greater the amount of probiotics that will be encapsulated. The highest encapsulation efficiency was attributed to the fact that this treatment did not prevent adsorbed layers; therefore, a greater capacity for hydration and gel formation was possible, since each time a layer was adsorbed there was a reduction in encapsulation efficiency. By contrast, LA/P1, LA/P2 and LA/P3 treatments had particle compositions, whey protein concentrate and pectin concentration in different proportions, hat promoted a reduction in encapsulation efficiency. CHEN et al. (2017) also observed a reduction in encapsulation efficiency when using multilayer microcapsules to encapsulate Bifidobacterium bifidum BB01, whereas GEBARA et al. (2013) obtained satisfactory encapsulation results above $80 \%$ when producing pectin microcapsules coated with whey protein concentrate. However, encapsulation efficiency is variable depending on the technique used, the bioactive compound being encapsulated and the composition of the encapsulating agent. According to CHOTIKO \& SATHIVEL, (2016), encapsulation efficiency increased when the rice bran concentration of the pectin particle was increased from 0.5 to $2 \%$.

In relation to the average particle size (Table 1), LA/P0 presented a larger particle size of $477.6 \mu \mathrm{m}$, differing significantly $(\mathrm{p}<0.05)$ from the other treatments. This was consistent with the high hydration capacity of pectin (MORRIS et al., 2010). SOUZA et al. (2012) also observed that pectin particles are noticeably larger than protein coated pectin particles because of differences in electrostatic interactions that occur between the respective molecules.

$\mathrm{LA} / \mathrm{P} 1, \mathrm{LA} / \mathrm{P} 2$ and $\mathrm{LA} / \mathrm{P} 3$ treatments produced smaller particle sizes of $236 \mu \mathrm{m}, 223 \mu \mathrm{m}$ and $208 \mu \mathrm{m}$, respectively. Particles with two layers of pectin (LA/P2) interacted electrostatically with the whey protein concentrate of the last layer (LA/ $\mathrm{P} 3$ ), with a reduction in the average particle size in relation to that obtained for LA/P2. It was proposed that incorporation of whey protein concentrate in the treatments promoted an expulsion of part of the water present in the pectin particles, reducing their moisture content; and consequently, their size, since pectin carboxyl groups perform electrostatic interactions with the protein in preference to water molecules (CROUZIERet al., 2010). AGUILAR et al. (2015) obtained sizes of $287 \mu \mathrm{m}$ when producing pectin particles with protein coatings, while GEREZ et al. (2012) produced particles with a size of $185 \mu \mathrm{m}$.

\section{Morphological characterization of microcapsules Lactobacillus acidophilus distributed} homogeneously in the different microcapsule types (Figure 1, first column), which had similar spherical and slightly oval forms, even though their composition was different. SOUZA et al. (2012) also reported that encapsulated material was homogeneously distributed in every protein coated pectin particle. TLA/P3 microcapsules had thicker walls in comparison to those produced by other treatments, because these particles were formed by three coating layers. While images obtained by SEM (Figure 1, second column) depicted Lactobacillus acidophilus homogeneously distributed on the surface of the microcapsules, the lyophilisation process mischaracterized the shape of the microcapsules, showing collapse of their structure, especially for LA/P3. According to SOUZA et al. (2012), many factors might have led to greater fragility of the particles during the drying process; among these, encapsulating matrix based on pectin of low esterification content contained a large amount of water. BELŠČCK-CVITANOVIĆ et al. (2015) and GADALLA et al. (2015) also observed changes in the morphological characteristics of pectin-containing microcapsules.

Evaluation of survival of Lactobacillus acidophilus after exposure to simulated gastrointestinal conditions Exposure to the different $\mathrm{pHs}$ that simulated the passage through the gastrointestinal tract showed that LA/P0, LA/P1 and LA/P3 microcapsules were able to protect probiotics, when compared to viability of free bacterial cells (Table 2). In the simulation of passage through the gastric compartment $(\mathrm{pH}$ 2.0 for $90 \mathrm{~min}$.), there was a release of probiotics from all treatments. Free cells showed a reduction of $7.69 \log \mathrm{CFU} / \mathrm{g}^{-1}$, microencapsulated probiotics had reduction ranging from $5.8 \log \mathrm{CFU} / \mathrm{g}^{-1}$ (LA/P0) 

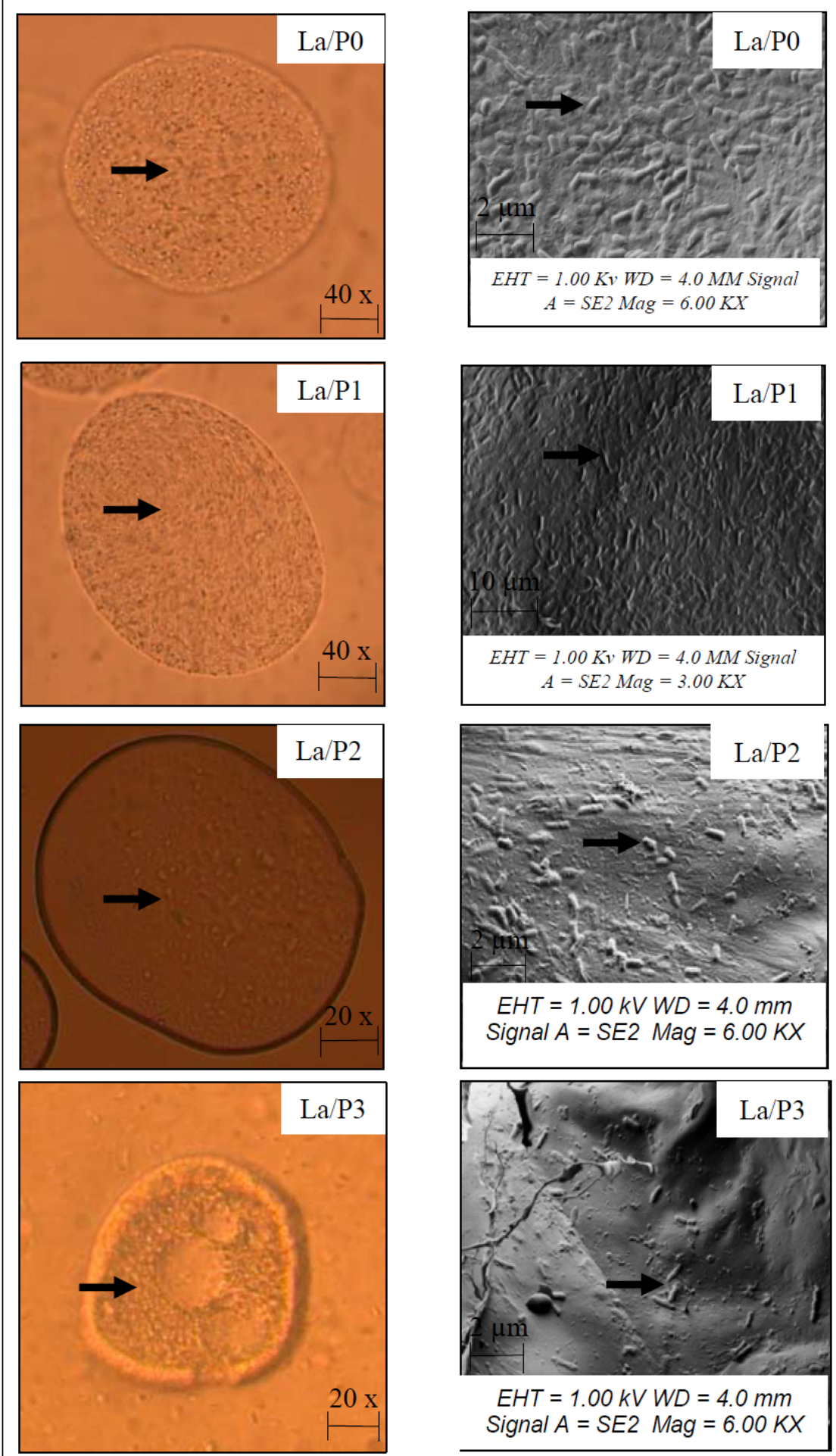

Figure 1 - Optical microscopy (first column) and scanning electron microscopy (SEM) (second column) of pectin and pectin microcapsules with multilayers containing L. acidophilus.

$\mathrm{LA} / \mathrm{P} 0=$ Pectin capsule $(40 \mathrm{x}) ; \mathrm{LA} / \mathrm{P} 1=$ Pectin capsule +1 coating $(40 \mathrm{x}) ; \mathrm{LA} / \mathrm{P} 2=$ Pectin capsule +2 coatings $(20 \mathrm{x}) ; \mathrm{LA} / \mathrm{P} 3=$ Pectin capsule +3 coatings $(20 \mathrm{x})$. The arrows indicate the presence of probiotics. 
Table 2 - Viability of free and microencapsulated Lactobacillus acidophilus exposed to different simulation conditions of the gastrointestinal tract.

\begin{tabular}{ccccccc}
\hline Min. & $\mathrm{pH}$ & Free cell & $\mathrm{La} / \mathrm{P} 0$ & $\mathrm{La} / \mathrm{P} 1$ & $\mathrm{La} / \mathrm{P} 2$ & $\mathrm{La} / \mathrm{P} 3$ \\
\hline 0 & - & $13.24 \pm 0.08^{\mathrm{Aa}}$ & $11.71 \pm 0.05^{\mathrm{Aa}}$ & $9.60 \pm 0.01^{\mathrm{Ad}}$ & $8.29 \pm 0.04^{\mathrm{Ae}}$ & $10.24 \pm 0.05^{\mathrm{Ac}}$ \\
90 & 2.0 & $5.55 \pm 0.00^{\mathrm{Bc}}$ & $5.91 \pm 0.02^{\mathrm{Db}}$ & $7.87 \pm 0.01^{\mathrm{Da}}$ & $3.67 \pm 0.03^{\mathrm{Be}}$ & $5.22 \pm 0.02^{\mathrm{Dd}}$ \\
110 & 5.0 & $5.20 \pm 0.04^{\mathrm{BCc}}$ & $6.64 \pm 0.03^{\mathrm{Cb}}$ & $8.21 \pm 0.06^{\mathrm{Ca}}$ & $3.85 \pm 0.01^{\mathrm{Bd}}$ & $6.37 \pm 0.04^{\mathrm{Cb}}$ \\
200 & 6.5 & $4.93 \pm 0.07^{\mathrm{Cd}}$ & $7.58 \pm 0.01^{\mathrm{Bc}}$ & $9.24 \pm 0.04^{\mathrm{Bb}}$ & $3.88 \pm 0.00^{\mathrm{Be}}$ & $9.81 \pm 0.02^{\mathrm{Ba}}$ \\
\hline
\end{tabular}

Means followed by the same capital letters in the column do not differ statistically from each other by the Tukey test at $5 \%$ significance. Different lowercase letters in the same row differ statistically from each other by the Tukey test at $5 \%$ significance.

The mean values were obtained in triplicate. LA/P0 $=$ L. acidophilus encapsulated in $2 \%$ pectin microcapsule $($ control); $\mathrm{LA} / \mathrm{P} 1=L$. acidophilus encapsulated in $2 \%$ pectin microcapsule +1 layer of $2 \%$ whey protein concentrate; LA/P2 $=$ L. acidophilus encapsulated in $2 \%$ pectin microcapsule +1 layer of $2 \%$ whey protein concentrate +1 layer of $0.3 \%$ pectin; LA/P3 $=$ L. acidophilus encapsulated in $2 \%$ pectin microcapsule +1 layer of $2 \%$ whey protein concentrate +1 layer of $0.3 \%$ pectin $+0.5 \%$ whey protein concentrate.

to $1.73 \log \mathrm{CFU} / \mathrm{g}^{-1}(\mathrm{LA} / \mathrm{P} 1)$. Consistent with the current study, ECTHEPARE et al. (2016) reported that survival of Lactobacillus acidophilus cells in the gastric portion of the gastrointestinal tract was higher in microcapsules formed by alginate coated with chitosan, compared to alginate microcapsules. This was due to the strong electrostatic interaction between the two components, as happened with LA/ P1 microcapsules, formed by pectin coated with protein, and which showed less loss of viability Lactobacillus acidophilus. CHEN et al. (2017) also observed that encapsulation in a layer or double layer was significant for the survival of B. bifidum in simulated passage through gastric juices, when compared to free cells.

In the simulated passage through the small intestines ( $\mathrm{pH} 5.0$ for $110 \mathrm{~min}$.), there was a significantly higher release of microorganisms from LA/P0, LA/P1 and LA/P3 microcapsules $(\mathrm{p}<0.05)$, compared to that at the previous gastric $\mathrm{pH}$. By contrast free cells and LA/P2 particles showed no significant difference $(\mathrm{p}>0.05)$ in their release of microorganisms at $\mathrm{pH} 5.0$, compared to that at $\mathrm{pH}$ 2.0. The viability of Lactobacillus acidophilus for the LA/P2 particles was reduced $4.62 \log \mathrm{CFU} / \mathrm{g}^{-1}$ when exposed to the gastric juice, and maintained low counts at pHs 5.0 and 6.5 during the simulated conditions, demonstrating that these probiotics did not resist passage through the gastrointestinal tract, similarly to free cells. Under these conditions, the microorganisms were not viable to colonize the intestines. ASSADPOUR et al. (2017) evaluated the folic acid-release profile of nanoparticles produced with pectin and whey protein concentrate, and, in general, the release rate was higher at alkaline $\mathrm{pH}$.
This was considered satisfactory as the main goal of the study was to resist the acidic conditions of the stomach. In addition, microcapsules produced with pectin have previously been shown not to be digested by gastric enzymes, and remain intact in the upper gastrointestinal tract(RAYMENT et al., 2009).Ultimately, they are disrupted after fermentation in the colon, requiring a long residence time in the intestinal environment for release of the encapsulated material.

The survival of cells in the ileum simulation (pH 6.5 for 200 min.) was higher in pectin microcapsules coated with whey protein concentrate $\left(\mathrm{LA} / \mathrm{P} 1=9.24 \log \mathrm{CFU} / \mathrm{g}^{-1}\right.$ and $\mathrm{LA} / \mathrm{P} 3=9.81 \mathrm{log}$ $\mathrm{CFU} / \mathrm{g}^{-1}$ ), compared to free cells (4.93 log $\mathrm{CFU} / \mathrm{g}^{-1}$ ) and the pectin particles $\left(\mathrm{LA} / \mathrm{P} 0=7.58 \mathrm{log} \mathrm{CFU} / \mathrm{g}^{-1}\right)$. This result reinforced the effectiveness of using whey protein concentrate to coat probiotic particles, with multilayer treatments showing greater viability for Lactobacillus acidophilus. Previous studies have indicated satisfactory results with coated pectin microcapsules when exposed to gastric conditions and bile salts, with encapsulated bacteria showing greater viability when compared to free cells (GADALLA et al., 2015; CHOTIKO \& SATHIVEL, 2016; ASSADPOUR et al.,2017).

Survival of Lactobacillus acidophilus after heat treatment

Free cells and LA/P0, LA/P1, LA/P2 and $\mathrm{LA} / \mathrm{P} 3$ microcapsules exposed to heat treatment at $72^{\circ} \mathrm{C}$ for $15 \mathrm{~s}$, simulating the fast pasteurization process, showed significant differences in Lactobacillus acidophilus viability compared to the initial count $(\mathrm{p}<0.05$; Table 3$)$. The reductions in Lactobacillus 
Table 3 - Viability of free and microencapsulated Lactobacillus acidophilus under heat treatments.

\begin{tabular}{lccccc}
\hline Treatment & Free cell & $\mathrm{La} / \mathrm{P} 0$ & $\mathrm{La} / \mathrm{P} 1$ & $\mathrm{La} / \mathrm{P} 2$ & $\mathrm{La} / \mathrm{P} 3$ \\
\hline Initial count & $13.24 \pm 0.08^{\mathrm{Aa}}$ & $11.71 \pm 0.05^{\mathrm{Ab}}$ & $9.60 \pm 0.01^{\mathrm{Ad}}$ & $8.29 \pm 0.04^{\mathrm{Ae}}$ & $10.24 \pm 0.05^{\mathrm{Ac}}$ \\
$75^{\circ} \mathrm{C} / 15 \mathrm{~s}$ & $7.84 \pm 0.13^{\mathrm{Ba}}$ & $7.17 \pm 0.04^{\mathrm{Ca}}$ & $7.46 \pm 0.05^{\mathrm{Ba}}$ & $5.61 \pm 0.13^{\mathrm{Bc}}$ & $6.19 \pm 0.05^{\mathrm{Cb}}$ \\
$63^{\circ} \mathrm{C} / 30 \mathrm{~min}$. & $4.66 \pm 0.00^{\mathrm{Cd}}$ & $8.22 \pm 0.00^{\mathrm{Bc}}$ & $9.57 \pm 0.05^{\mathrm{Aa}}$ & $4.12 \pm 0.00^{\mathrm{Cc}}$ & $8.64 \pm 0.03^{\mathrm{Bb}}$ \\
\hline
\end{tabular}

Means and standard deviation followed by different capital letters in the column differ statistically from each other by the Tukey test at $5 \%$ significance. Different lowercase letters in the same row differ statistically from each other by the Tukey test at $5 \%$ significance. The mean values were obtained in triplicate.

acidophilus were $4.47 \log \mathrm{CFU}(\mathrm{LA} / \mathrm{P} 0), 2.14 \log$ $\mathrm{CFU} / \mathrm{g}^{-1}(\mathrm{LA} / \mathrm{P} 1), 2.68 \log \mathrm{CFU} / \mathrm{g}^{-1}(\mathrm{LA} / \mathrm{P} 2)$, and 4.05 $\log \mathrm{CFU} / \mathrm{g}^{-1}(\mathrm{LA} / \mathrm{P} 3)$, and $5.4 \log \mathrm{CFU} / \mathrm{g}^{-1}$ for the free culture. These results demonstrated that regardless of the composition of the microcapsules, encapsulated Lactobacillus acidophilus resisted heat treatment more successfully than the free microorganism. In addition, even though encapsulated counts were reduced, the microcapsules were structurally resistant. Notably, LA/P0 was the most heat sensitive particle, due to its greater hydration and porosity, and lacking the overlay of different components. According to TELLO et al. (2015), particles produced with pectin have a noticeably more fragile texture than those generated with alginate, for instance. This might be because pectin has amide groups in its structure; and therefore, a smaller number of carboxyl groups available to form ionic bonds, resulting in the incorporation of less calcium and hence weaker particles. As such, the adsorption of protein layers by electrostatic interactions to the pectin particles was used in this study to investigate the viability of probiotics after exposure to adverse conditions. After exposure to the heat treatment at $72{ }^{\circ} \mathrm{C}$ for $15 \mathrm{~s}$, microorganisms present in the microcapsules LA/P0 (7.17 log CFU/g-1), LA/P1 (7.46 log CFU/g-1) and LA/P3 (6.19 log CFU/g-1) showed viability, while microorganisms in the LA/P2 microcapsules showed a reduction in viability $(5.61 \log \mathrm{CFU} / \mathrm{g}-1)$.

Free cells and LA/P0, LA/P2 and LA/P3 microcapsules exposed to heat treatment at $63^{\circ} \mathrm{C}$ for 30 min., simulating the slow pasteurisation process, showed significant differences in Lactobacillus acidophilus viability compared to the initial count $(\mathrm{p}<0.05)$. By contrast, LA/P1 microcapsules showed no significant difference in bacterial numbers ( $p>0.05)$ over the initial count, demonstrating that the microcapsules protected and maintained the viability of Lactobacillus acidophilus (9.57 log $\left.\mathrm{CFU} / \mathrm{g}^{-1}\right)$. The reductions of L.acidophilus were 3.42 $\log \mathrm{CFU} / \mathrm{g}^{-1}(\mathrm{LA} / \mathrm{P} 0), 4.17 \log \mathrm{CFU} / \mathrm{g}^{-1}$ (LA/P2) and $1.60 \log \mathrm{CFU} / \mathrm{g}^{-1}(\mathrm{LA} / \mathrm{P} 3)$, and $8.58 \log \mathrm{CFU} / \mathrm{g}^{-1}$ for the free culture. Furthermore, microorganisms contained in microcapsules LA/P0 and LA/P3 showed viabilities of $8.22 \mathrm{log} \mathrm{CFU} / \mathrm{g}^{-1}$ and $8.64 \mathrm{log}$ $\mathrm{CFU} / \mathrm{g}^{-1}$, respectively.

\section{Viability of Lactobacillus acidophilus at different} storage temperatures

Table 4 show the viability of microencapsulated and free Lactobacillus acidophilus stored for 120 days at $5{ }^{\circ} \mathrm{C}, 25{ }^{\circ} \mathrm{C}$ and $-18{ }^{\circ} \mathrm{C}$. LA/P0 microparticles maintained the viability of probiotics for 75 days during storage at $5^{\circ} \mathrm{C}$ and $25^{\circ} \mathrm{C}$, with counts of $6.61 \log \mathrm{CFU} / \mathrm{g}^{-1}$ and $7.07 \log \mathrm{CFU} / \mathrm{g}^{-1}$, respectively. LA/P1 microparticle maintained viability of probiotics for 60 days at $5{ }^{\circ} \mathrm{C}$; however, they showed high viability at 120 days of storage at $-18{ }^{\circ} \mathrm{C}$, with counts of $7.86 \mathrm{log}$ $\mathrm{CFU} / \mathrm{g}^{-1}$. LA/P2 microparticle maintained viability of probiotics for 45 days at $5{ }^{\circ} \mathrm{C}$, with counts of 6.14 $\log \mathrm{CFU} / \mathrm{g}^{-1}$. Similarly to $\mathrm{LA} / \mathrm{P} 1, \mathrm{LA} / \mathrm{P} 3$ was also resistant to freezing temperatures, showing high viability and counts of $6.55 \mathrm{log} \mathrm{CFU} / \mathrm{g}^{-1}$ at 105 days of storage. The data showed that microcapsules with whey protein in their last layer, LA/P1 and LA/P3, were more resistant to frozen storage. Treatments with pectin on the external surface, LA/P0 and LA/ $\mathrm{P} 2$, showed better viability on refrigerated storage $\left(5^{\circ} \mathrm{C}\right)$; although, with inferior shelf-life than the other treatments. Free Lactobacillus acidophilus presented inferior performance compared to microencapsulated bacteria, in cooling and freezing temperature, since they maintained viability for approximately 60 days, continuing to show decreased survival until the end of their shelf-life. Studies performed by MARQUES DA SILVA et al. (2018) and HOLKEM et al. (2017) showed that the stability of microencapsulated probiotics was superior at low temperatures, compared to free bacteria. 
Table 4 - Viability of free and microencapsulated Lactobacillus acidophilus with and without multilayers during 120 days of storage at room temperature $\left(25^{\circ} \mathrm{C}\right)$, freezing $\left(-18^{\circ} \mathrm{C}\right)$, and refrigeration $\left(5^{\circ} \mathrm{C}\right)$.

\begin{tabular}{|c|c|c|c|c|c|}
\hline Treatment Time (Days) & Free Cell & LA/P0 & LA/P1 & LA/P2 & LA/P3 \\
\hline 0 & $13.24 \pm 0.08^{\mathrm{Aa}}$ & $11.71 \pm 0.05^{\mathrm{Ba}}$ & $9.60 \pm 0.01^{\mathrm{Da}}$ & $8.29 \pm 0.04^{\mathrm{Ea}}$ & $10.24 \pm 0.05^{\mathrm{Ca}}$ \\
\hline 15 & $10.07 \pm 0.09^{\mathrm{Ab}}$ & $10.61 \pm 0.12^{\mathrm{Ab}}$ & $8.46 \pm 0.06^{\mathrm{Bb}}$ & $6.84 \pm 0.05^{\mathrm{Cb}}$ & $8.95 \pm 0.03^{\mathrm{Bb}}$ \\
\hline 30 & $9.75 \pm 0.21^{\mathrm{Ab}}$ & $9.42 \pm 0.01^{\mathrm{Ac}}$ & $7.31 \pm 0.05^{\mathrm{Cc}}$ & $5.28 \pm 0.11^{\mathrm{Dc}}$ & $8.75 \pm 0.01^{\mathrm{Bc}}$ \\
\hline 45 & $7.89 \pm 0.01^{\mathrm{Ac}}$ & $8.38 \pm 0.11^{\mathrm{Ad}}$ & $6.78 \pm 0.05^{\mathrm{Bd}}$ & $4.91 \pm 0.07^{\mathrm{Cd}}$ & $8.08 \pm 0.03^{\mathrm{Ad}}$ \\
\hline 60 & $7.83 \pm 0.01^{\mathrm{Ac}}$ & $7.07 \pm 0.06^{\mathrm{Ac}}$ & $5.09 \pm 0.01^{\mathrm{Be}}$ & $3.50 \pm 0.11^{\mathrm{Cd}}$ & $5.53 \pm 0.04^{\mathrm{Be}}$ \\
\hline 75 & $7.65 \pm 0.01^{\mathrm{Ac}}$ & $6.37 \pm 0.11^{\mathrm{Bf}}$ & $4.85 \pm 0.08^{\mathrm{Ce}}$ & $0.0^{\mathrm{Ee}}$ & $3.45 \pm 0.01^{\mathrm{Df}}$ \\
\hline 90 & $7.49 \pm 0.02^{\mathrm{Ac}}$ & $5.22 \pm 0.02^{\mathrm{Bg}}$ & $4.10 \pm 0.05^{\mathrm{Cg}}$ & $0.0^{\mathrm{Ee}}$ & $2.66 \pm 0.11^{\mathrm{Df}}$ \\
\hline 105 & $6.20 \pm 0.02^{\mathrm{Ad}}$ & $0.0^{\mathrm{Ch}}$ & $3.27 \pm 0.06^{\mathrm{Bg}}$ & $0.0^{\mathrm{Ce}}$ & $0.0^{\mathrm{Cg}}$ \\
\hline 120 & $5.07 \pm 0.03^{\mathrm{Ae}}$ & $0.0^{\mathrm{Bh}}$ & $0.0^{\mathrm{Bh}}$ & $0.0^{\mathrm{Be}}$ & $0.0^{\mathrm{Bg}}$ \\
\hline \multicolumn{2}{|c|}{---------------------Temperature------------------- } & \multicolumn{4}{|c|}{ 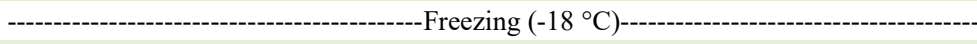 } \\
\hline Treatment Time (Days) & Free Cell & $\mathrm{LA} / \mathrm{P} 0$ & $\mathrm{LA} / \mathrm{P} 1$ & $\mathrm{LA} / \mathrm{P} 2$ & LA/P3 \\
\hline 0 & $13.24 \pm 0.08^{\mathrm{Aa}}$ & $11.71 \pm 0.05^{\mathrm{Ba}}$ & $9.60 \pm 0.01^{\mathrm{Da}}$ & $8.29 \pm 0.04^{\mathrm{Ea}}$ & $10.24 \pm 0.05^{\mathrm{Ca}}$ \\
\hline 15 & $11.56 \pm 0.01^{\mathrm{Ab}}$ & $10.36 \pm 0.03^{\mathrm{Bb}}$ & $8.83 \pm 0.02^{\text {Dab }}$ & $8.69 \pm 0.03^{\mathrm{Da}}$ & $9.56 \pm 0.22^{\mathrm{Ca}}$ \\
\hline 30 & $10.75 \pm 0.01^{\mathrm{Ac}}$ & $8.76 \pm 0.07^{\mathrm{Cc}}$ & $8.60 \pm 0.18^{\mathrm{Ccd}}$ & $8.38 \pm 0.06^{\mathrm{Ca}}$ & $9.39 \pm 0.05^{\mathrm{Ba}}$ \\
\hline 45 & $10.40 \pm 0.03^{\mathrm{Ac}}$ & $6.66 \pm 0.06^{\mathrm{Cd}}$ & $8.49 \pm 0.01^{\mathrm{Bcd}}$ & $5.56 \pm 0.04^{\mathrm{Db}}$ & $8.48 \pm 0.11^{\mathrm{Bb}}$ \\
\hline 60 & $5.74 \pm 0.08^{\mathrm{Cd}}$ & $5.64 \pm 0.13^{\mathrm{Ce}}$ & $8.32 \pm 0.05^{\text {Acd }}$ & $5.55 \pm 0.03^{\mathrm{Cb}}$ & $7.16 \pm 0.02^{\mathrm{Bc}}$ \\
\hline 75 & $5.61 \pm 0.01^{\mathrm{Cd}}$ & $5.35 \pm 0.13^{\mathrm{Ce}}$ & $8.19 \pm 0.04^{\text {Acd }}$ & $5.52 \pm 0.02^{\mathrm{Cb}}$ & $7.14 \pm 0.03^{\mathrm{Bc}}$ \\
\hline 90 & $4.94 \pm 0.06^{\mathrm{Ce}}$ & $3.53 \pm 0.09^{\mathrm{Df}}$ & $8.03 \pm 0.06^{\text {Acd }}$ & $5.26 \pm 0.04^{\mathrm{Cb}}$ & $7.02 \pm 0.07^{\mathrm{Bc}}$ \\
\hline 105 & $4.14 \pm 0.11^{\mathrm{Cf}}$ & $3.23 \pm 0.03^{\mathrm{Df}}$ & $7.86 \pm 0.15^{\text {Acd }}$ & $4.72 \pm 0.11^{\mathrm{Cbd}}$ & $6.55 \pm 0.03^{\mathrm{Bd}}$ \\
\hline 120 & $3.35 \pm 0.02^{\mathrm{Cg}}$ & $0.0^{\mathrm{Dg}}$ & $7.66 \pm 0.21^{\mathrm{Ad}}$ & $4.49 \pm 0.08^{\mathrm{Bd}}$ & $0.0^{\mathrm{Dc}}$ \\
\hline \multicolumn{2}{|c|}{---------------------Temperature------------------ } & \multicolumn{4}{|c|}{ 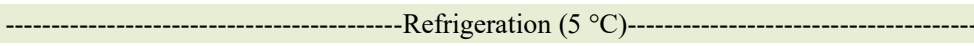 } \\
\hline Treatment Time (Days) & Free Cell & LA/P0 & LA/P1 & LA/P2 & LA/P3 \\
\hline 0 & $13.24 \pm 0.08^{\mathrm{Aa}}$ & $11.71 \pm 0.05^{\mathrm{Ba}}$ & $9.60 \pm 0.01^{\mathrm{Da}}$ & $8.29 \pm 0.04^{\mathrm{Ea}}$ & $10.24 \pm 0.05^{\mathrm{Ca}}$ \\
\hline 15 & $10.44 \pm 0.14^{\mathrm{Ab}}$ & $9.62 \pm 0.03^{\mathrm{Bb}}$ & $8.31 \pm 0.09^{\mathrm{Cb}}$ & $6.77 \pm 0.06^{\mathrm{Db}}$ & $9.68 \pm 0.15^{\mathrm{Ba}}$ \\
\hline 30 & $8.31 \pm 0.06^{\mathrm{Bc}}$ & $9.20 \pm 0.05^{\mathrm{Ab}}$ & $8.07 \pm 0.14^{\mathrm{Bb}}$ & $6.61 \pm 0.09^{\mathrm{Cb}}$ & $9.65 \pm 0.13^{\mathrm{Aa}}$ \\
\hline 45 & $7.89 \pm 0.01^{\mathrm{Ac}}$ & $7.25 \pm 0.04^{\mathrm{Ab}}$ & $7.66 \pm 0.07^{\mathrm{Abc}}$ & $6.14 \pm .02^{\mathrm{Bbc}}$ & $6.57 \pm 0.01^{\mathrm{Bb}}$ \\
\hline 60 & $6.03 \pm 0.05^{\mathrm{ABd}}$ & $6.61 \pm 0.08^{\mathrm{Ad}}$ & $6.45 \pm 0.02^{\mathrm{Ac}}$ & $5.61 \pm 0.02^{\mathrm{Bcd}}$ & $6.39 \pm 0.02^{\mathrm{Ab}}$ \\
\hline 75 & $3.10 \pm 0.04^{\mathrm{Ce}}$ & $6.60 \pm 0.02^{\mathrm{Ad}}$ & $5.01 \pm 0.03^{\mathrm{Bd}}$ & $5.59 \pm 0.03^{\mathrm{Bcd}}$ & $5.65 \pm 0.01^{\mathrm{Bc}}$ \\
\hline 90 & $2.67 \pm 0.22^{\mathrm{Ce}}$ & $5.96 \pm 0.08^{\mathrm{Ae}}$ & $4.77 \pm 0.10^{\mathrm{Bd}}$ & $5.54 \pm 0.03^{\mathrm{Acd}}$ & $5.28 \pm 0.08^{\mathrm{Ac}}$ \\
\hline 105 & $0.0^{\mathrm{Df}}$ & $5.45 \pm 0.03^{\mathrm{Ae}}$ & $3.20 \pm 0.11^{\mathrm{Ce}}$ & $5.38 \pm 0.20^{\mathrm{Ad}}$ & $4.71 \pm 0.01^{\mathrm{ABd}}$ \\
\hline 120 & $0.0^{\mathrm{Cf}}$ & $4.42 \pm 0.01^{\mathrm{Bf}}$ & $0.0^{\mathrm{Bf}}$ & $5.30 \pm 0.02^{\mathrm{Ad}}$ & $4.61 \pm 0.05^{\mathrm{Bd}}$ \\
\hline
\end{tabular}

$\mathrm{LA} / \mathrm{P} 0=$ L. acidophilus encapsulated in $2 \%$ pectin microcapsule (control); LA/P1 = L. acidophilus encapsulated in $2 \%$ pectin microcapsule +1 layer of $2 \%$ whey protein concentrate; LA/P2 $=$ L. acidophilus encapsulated in $2 \%$ pectin microcapsule +1 layer of $2 \%$ whey protein concentrate +1 layer of $0.3 \%$ pectin; LA/P3 $=$ L. acidophilus encapsulated in $2 \%$ pectin microcapsule +1 layer of $2 \%$ whey protein concentrate +1 layer of $0.3 \%$ pectin $+0.5 \%$ whey protein concentrate.Means followed by the same letter, lowercase in the column and upper case in the row, do not differ statistically from each other by Tukey test at $5 \%$ significance. Means found in triplicate.

\section{CONCLUSION}

The production of microcapsules by external ionic gelation, followed by multilayer coating by electrostatic interaction of pectin polyelectrolytes and whey protein concentrate, proved to be feasible in maintaining the viability of Lactobacillus acidophilus. Pectin as a coating material resisted gastric enzymes and simulated gastrointestinal conditions, undergoing hydrolysis by microflora in the colon. Bacteria in microcapsules also resisted to high temperatures and prolonged storage, compared to free bacteria.

Results of this study and previous reports indicated variability in particle size resulting from the external ionic gelation technique. To achieve uniform sizes, the conditions of production need standardization, in particular, the spray rate of the solution, the concentrations of the solutions, the distance between the solution and the spray nozzle, and the rate of stirring of the solution. 
This study indicated that external ionic gelation was effective and could be used for the production of pectin microcapsules with whey protein concentrate multilayers to promote greater protection and viability of Lactobacillus acidophilus .

\section{ACKNOWLEDGEMENTS}

This study was financed in part by the Coordenação de Aperfeiçoamento de Pessoal de Nível Superior - Brasil (CAPES) - Finance Code 001",

\section{DECLARATION OF CONFLICT OF INTERESTS}

The authors declare no conflict of interest. The founding sponsors had no role in the design of the study; in the collection, analyses, or interpretation of data; in the writing of the manuscript, and in the decision to publish the results.

\section{AUTHORS' CONTRIBUTIONS}

The authors contributed equally to the manuscript.

\section{REFERENCES}

AGUILAR, K.C. et al. Protein adsorption onto alginate-pectin microparticles and films produced by ionic gelation. Journal of Food Engineering, v.154, p.17-24, 2015. Available from: <http:// dx.doi.org/10.1016/j.jfoodeng.2014.12.020>. Accessed: May, 01, 2017. doi: 10.1016/j.jfoodeng.2014.12.020

ANAL, A.K.; SINGH, H. Recent advances in microencapsulation of probiotics for industrial applications and targeted delivery. Trends in Food Science \& Technology, v.18, n.5, p.240-251, 2007. Available from: <http://dx.doi.org/10.1016/j.tifs.2007.01.004> Accessed: May, 11, 2017. doi: 10.1016/j.tifs.2007.01.004.

ANNAN, N.T. et al. Encapsulation in alginate-coated gelatin microspheres improves survival of the probiotic Bifidobacterium adolescentis $15703 \mathrm{~T}$ during exposure to simulated gastro-intestinal conditions. Food Research International, v.41, p.184-193, 2008. Available from: <http://dx.doi.org/10.1016/j.foodres.2007.11.001>. Accessed: Nov. 12, 2018. doi: 10.1016/j.foodres.2007.11.001.

ASSADPOUR, E. et al.Evaluation of folic acid release from spray dried powder particles of pectin-whey protein nano-capsules. International Journal of Biological Macromolecules, v.95, p.238-247, 2017. Available from: <http://dx.doi.org/10.1016/j. ijbiomac.2016.11.023>. Accessed: Nov. 12, 2018. doi: 10.1016/j. ijbiomac.2016.11.023.

BELŠČAK-CVITANOVIĆ, A. et al. Protein-reinforced and chitosan-pectin coated alginate microparticles for delivery of flavan-3-ol antioxidants and caffeine from green tea extract.Food Hydrocolloids, v.51, p.01-54, 2015. Available from: <http:// dx.doi.org/10.1016/j.foodhyd.2015.05.039>. Accessed: Oct. 28, 2018. doi: 10.1016/j.foodhyd.2015.05.039.

CHAMPAGNE, C.P.et al. Recommendations for the viability assessment of probiotics as concentrated cultures and in food matrices. International Journal of Food Microbiology, v.149, p.185-193, 2011. Available from: <http://dx.doi.org/10.1016/j. ijfoodmicro.2011.07.005>. Accessed: Oct. 28, 2018. doi: 10.1016/j.ijfoodmicro.2011.07.005.

CHEN, L. et al. Effect of xanthan-chitosan-xanthan double layer encapsulation on survival of Bifidobacterium BB01 in simulated gastrointestinal conditions, bile salt solution and yogurt. LWT Food Science and Technology, v.81, p.274-280, 2017. Available from: <http://dx.doi.org/10.1016/j.lwt.2017.04.005>. Accessed: Oct. 28, 2018. doi: 10.1016/j.lwt.2017.04.005

CHOTIKO, A.; SATHIVEL, S. Development of a combined lowmethoxyl-pectin and rice-bran-extract delivery system to improve the viability of Lactobacillus plantarum under acid and bile conditions. LWT - Food Science and Technology, v.66, p.420-427, 2016. Available from: $<$ http://dx.doi.org/10.1016/j.lwt.2015.10.058>. Accessed: Nov. 12, 2018. doi: 10.1016/j.lwt.2015.10.058.

CROUZIER, T. et al. Polysaccharide-based polyelectrolytemultilayers. Current Opinion in Colloid \& Interface Science, v.15, p.417-426, 2010. Available from: $<\mathrm{http} / / \mathrm{dx}$.doi.org/10.1016/j.cocis.2010.05.007>. Accessed: Jun. 28, 2018. doi: 10.1016/j.cocis.2010.05.007.

DE VOS, P. et al. Encapsulation for preservation of functionality and targeted delivery of bioactive food components. International Dairy Journal, v.20, n.4, p.292-302, 2010. Available from: $<$ http://dx.doi.org/10.1016/j.idairyj.2009.11.008>. Accessed: Apr. 20, 2017. doi: 10.1016/j.idairyj.2009.11.008.

DOHERTY, S.B.et al. Development and characterisation of whey protein micro-beads as potential matrices for probiotic protection. Food Hydrocolloids, v.25, p.1604-1617, 2011. Available from: $<$ http://dx.doi.org/10.1016/j.foodhyd.2010.12.012>. Accessed: Apr. 20, 2017. doi: 10.1016/j.foodhyd.2010.12.012.

ECTHEPARE, M.A. et al. Effect of resistant starch and chitosan on survival of Lactobacillus acidophilus microencapsulated with sodium alginate. LWT - Food Science and Technology, v.65, p.511-517, 2016. Available from: <http://dx.doi.org/10.1016/j.lwt.2015.08.039>. Accessed: Jun. 28, 2018. doi: 10.1016/j.lwt.2015.08.039.

GADALLA, H.H. et al. Development and in vitro/in vivo evaluation of $\mathrm{Zn}$-pectinate microparticles reinforced with chitosan for the colonic delivery of progesterone. Drug Delivery, v.23, n.7, p.2541-2554, 2015. Available from: <http://doi:10.3 109/10717544.2015.1028602>. Accessed: Jun. 10, 2017. doi: $10.3109 / 10717544.2015 .1028602$.

GBASSI, G.K. et al. In vitro effects of $\mathrm{pH}$, bile salts and enzymes on the release and viability of encapsulated Lactobacillus plantarum strains in a gastrointestinal tract model. International Dairy Journal, v.21, p.97-102, 2011. Available from: $<$ https://doi. org/10.1016/j.idairyj.2010.09.006>. Accessed: May, 01, 2017. doi: 10.1016/j.idairyj.2010.09.

GEBARA, C. et al. Viability of Lactobacillus acidophilus La5 in pectin-whey protein microparticles during exposure to simulated gastrointestinal conditions. Food Research International, v.51, p.872-878, 2013. Available from: <http://dx.doi.org/10.1016/j. foodres.2013.02.008>. Accessed: Apr. 20, 2017. doi: 10.1016/j. foodres.2013.02.008

GEREZ, C.L.et al. Whey protein coating bead improves the survival of the probiotic Lactobacillus rhamnosus CRL 1505 tolow pH. Letters in Applied Microbiology, v.54, p.552-556, 2012. Available from: <http://dx.doi.org/10.1111/ 
j.1472-765X.2012.03247.x>. Accessed: May, 11, 2017. doi: 10.1111/j.1472-765X.2012.03247.x.

HOLKEM, A.T. et al. Production of microcapsules containing Bifidobacterium BB-12 by emulsification/internal gelation. LWT - Food Science and Technology, v.76, p.216-221, 2017. Available from: <http://dx.doi.org/10.1016/j.1wt.2016.07.013>. Accessed: Jul. 30, 2018. doi: 10.1016/j.lwt.2016.07.013.

KAILASAPATHY, K.Encapsulation technologies for functional foods and nutraceutical product development.CAB Reviews: Perspectives in Agriculture, Veterinary Science, Nutrition and Natural Resources, v.4, n.33, 1-19, 2009. Available from: $<$ https://doi.org/10.1079/j.pavsnnr20094033>. Accessed: May, 01, 2017. doi: 10.1079/j.pavsnnr20094033.

KRASAEKOOPT, W. et al. The influence of coating materials on some properties of alginate beads and survivability of microencapsulated probiotic bacteria. International Dairy Journal, v.14, p.737-743, 2004. Available from: <https://doi. org/10.1016/j.idairyj.2004.01.004>. Accessed: Jun. 28, 2018. doi: 10.1016/j.idairyj.2004.01.004.

LIU, W. et al. Multilayered vitamin C nanoliposomes by selfassembly of alginate and chitosan: long-term stability and feasibility application in mandarin juice. LWT - Food Science and Technology, v.75, p.608-615, 2017. Available from: $<$ https:// doi.org/10.1016/j.1wt.2016.10.010>. Accessed: Jun. 28, 2018. doi: 10.1016/j.1wt.2016.10.010.

MADUREIRA, A. R. et al. Protective effect of whey cheese matrix on probiotic strains exposed to simulated gastrointestinal conditions. Food Research International, v.44, p.465-470, 2011. Available from: <https://doi.org/10.1016/j.foodres.2010.09.010>. Accessed: Jul. 30, 2018. doi: 10.1016/j.foodres.2010.09.010.

MARQUES DA SILVA, T. et al. Development and characterization of microcapsules containing Bifidobacterium $\mathrm{Bb}-12$ produced by complex coacervation followed by freeze drying. LWT - Food Science and Technology, v.90, p.412-417, 2018. Available from: $<$ https://doi.org/10.1016/j.lwt.2017.12.057>. Accessed: Jun. 28, 2018. doi: 10.1016/j.lwt.2017.12.057.

MORRIS, G.A. et al. Polysaccharide drug delivery systems based on pectin and chitosan. Biotechnology and Genetic Engineering Reviews, v.27, p.257-284, 2010. Available from: <http://dx.doi.or g/10.1080/02648725.2010.10648153>. Accessed: Jul. 30, 2018. doi: $10.1080 / 02648725.2010 .10648153$.

OLIVEIRA, A.C. et al. Stability of microencapsulated B. lactis (BI 01 ) and $L$. acidophilus (LAC 4) by complex coacervation followed by spray drying. Journal of Microencapsulation, v.24, p.685-693, 2007. Available from: <http://dx.doi.org/10.1080/07373930701590939>. Accessed: Apr. 20, 2017. doi: 10.1080/07373930701590939.

PICOT, A.; LACROIX, C. Encapsulation of bifidobacteria in whey protein-based microcapsules and survival in simulated gastrointestinal conditions and in yoghurt. International Dairy
Journal, v.14, p.505-515, 2004. Available from: <http://dx.doi. org/10.1016/j.idairyj.2003.10.008>. Accessed: May, 01, 2017. doi: 10.1016/j.idairyj.2003.10.008.

RAYMENT, P. et al. Investigation of alginate beads for gastrointestinal functionality, Part 1: In vitro characterisation. Food Hydrocolloids, v.23, n.3, p.816-822, 2009. Available from: $<$ http://dx.doi.org/10.1016/j.foodhyd.2008.04.011>. Accessed: Apr. 20, 2017. doi: 10.1016/j.foodhyd.2008.04.011.

REID, G. (2008). Probiotics and prebiotics - progress and challenges. International Dairy Journal, v.18, p.969-975, 2008. Available from: $<\mathrm{http}: / / \mathrm{dx}$.doi.org/10.1016/j.idairyj.2007.11.025>. Accessed: May, 01, 2017. doi: 10.1016/j.idairyj.2007.11.025.

SALMINEN, H.; WEISS, J. Electrostatic adsorption and stability of whey protein-pectin complexes on emulsion interfaces. Food Hydrocolloids, v.35, p.410-419, 2014. Available from: <http:// dx.doi.org/10.1016/j.foodhyd.2013.06.020>. Accessed: Apr. 20, 2017. doi: 10.1016/j.foodhyd.2013.06.020.

SHEU, T.Y.;MARSHALL, R.T. Microentrapment of lactobacilli in calciumalginate gels. Journal of Food Science, v.58, n.3, p.557561, 1993. Available from: $<\mathrm{http}: / / \mathrm{dx}$.doi.org/10.3168/jds.S00220302(93)77523-2.>. Accessed: May, 01, 2017. doi: 10.3168/jds. S0022-0302(93)77523-2.

SOORO INGREDIENTES. Proteínas do soro de leite concentrado proteico (WPC) aplicações e funcionalidades. Foods Ingredients Brasil, n.28, 42-44, 2014. Available from: <http://revista-fi.com. br/upload arquivos/201606/2016060638816001467048932.pdf>. Accessed: Apr. 20, 2017.

SOUZA, F.N. et al. Production and characterization of microparticles containing pectin and whey proteins. Food Research International, v.49, p.560-566, 2012. Available from: $<$ http://dx.doi.org/10.1016/j.foodres.2012.07.041>. $\quad$ Accessed: May, 01, 2017. doi: 10.1016/j.foodres.2012.07.041.

TELLO, F.et al. Alginate and pectin-based particles coated with globular proteins: Production, characterization and anti-oxidative properties. Food Hydrocolloids, v.43, p.670-678, 2015. Available from: <http://dx.doi.org/10.1016/j.foodhyd.2014.07.029>. Accessed: May, 01, 2017. doi: 10.1016/j.foodhyd.2014.07.029.

WORLD GASTROENTEROLOGY ORGANISATION. Probióticos e prebióticos. Diretrizes Mundiais da Organização Mundial de Gastroenterologia, Guias Mundiais da WGO, outubro, 2011. Available from: <http://www.worldgastroenterology.org/UserFiles/ file/guidelines/probiotics-and-prebiotics-portuguese-2017.pdf> . Accessed: Jun. 28, 2018.

ZHANG, Y. et al. The increased viability of probiotic Lactobacillus salivarius NRRL B-30514 encapsulated in emulsions with multiple lipid-protein-pectin layers. Food Research International, v.71, p.9-15, 2015. Available from: <http://dx.doi.org/10.1016/j. foodres.2015.02.017>. Accessed: Jun. 28, 2018. doi: 10.1016/j. foodres.2015.02.017. 